\title{
Ensino Colaborativo no Terceiro Grau: Formação do Professor por Meio da Prática Reflexiva
}

\author{
Collaboratively Teaching at Undergraduate Level:
} Teacher Learning Through Analytical Team-Teaching

\author{
Eliane Hércules AUGUSTO-NAVARRO* \\ Cláudia Jotto KAWACHI** \\ Cristiane Oliveira CAMPOS-GONELLA*** \\ Daniela TERENZI****
}

Resumo: Neste trabalho apresentamos uma reflexão sobre a contribuição que o ensino colaborativo pode trazer à formação continuada do professor e discutimos ganhos tanto práticos como teóricos em nosso desenvolvimento profissional a partir da experiência do desenvolvimento de um trabalho em equipe em duas disciplinas

* Professora associada da Universidade Federal de São Carlos (UFSCar), onde trabalha no curso de Letras e no Programa de Pós-graduação em Linguística (PPGL). Ensina inglês há mais de 20 anos e seus principais temas de pesquisa incluem educação de professores, ensino-aprendizagem de gramática, inglês para propósitos específicos (ESP e EAP), análise de gêneros e materiais didáticos. Contato: eaugustonavarro@gmail.com

** Doutoranda do programa de Pós-Graduação em Linguística na UFSCar e desenvolve pesquisas nos temas: ensino de gramática como habilidade e cognição de professores de LI. Possui experiência na área de língua inglesa como professora em institutos de idioma e escolas da rede particular de ensino, bem como na área de formação de professores de LI. Contato: claudiajk@hotmail.com

*** Doutoranda na UFSCar. Trabalha como professora de língua inglesa em escolas de idiomas, escolas públicas e privadas de ensino regular, bem como atua na formação de professores. Sua pesquisa está voltada para a motivação dos aprendizes, cognição de professores e desenvolvimento de material didático. Contato: crisgonella@gmail.com

**** Doutoranda em Linguística na UFSCar. Tem experiência em escolas de idiomas, escolas de ensino regular e cursos de graduação. Em 2009, obteve o título de mestre ao apresentar trabalho cujo foco era os aspectos do ensino de gramática como habilidade. Contato: daniela.ufscar@gmail.com 
distintas (uma no curso de Letras e outra de inglês instrumental) ofertadas na Universidade Federal de São Carlos (UFSCar). A oportunidade desse trabalho colaborativo foi gerada por uma norma da CAPES que prevê o estágio de pós-graduandos em disciplinas da graduação e os reflexos dessa experiência geraram, em termos práticos, maior consistência e entusiasmo no planejamento e desenvolvimento das aulas, bem como do sistema avaliativo, além da oportunidade de aprendizado a partir da observação da atuação pedagógica de cada membro da equipe. Com relação ao desenvolvimento teórico-acadêmico, tivemos a oportunidade de estudar e discutir questões derivadas de nossa prática e observação conjunta em sala de aula, refletindo sobre cada problemática e pensando em possíveis encaminhamentos teoricamente embasados. Enfim, encontramos elementos que indicam ser desejável continuar e ampliar o estágio docente também na pós-graduação, quando os profissionais em formação continuada revelam estar bem preparados para refletir sobre as relações entre teoria, prática e encaminhamentos prático-teóricos no ensino-aprendizagem.

Palavras-chave: Formação continuada; Ensino colaborativo; Reflexão prático-teórica.

Abstract: The aim of this paper is to report and discuss the experience that the authors had by collaboratively teaching undergraduate students in two different classes, from diverse programs (one being a professorteacher education context and the other EAP). Their opportunity to work together derived from a norm established by CAPES that requires their financially supported graduate students to have some formal experience in teaching at undergraduate programs. Both, undergraduate classes and the graduate program in Linguistics where the authors have been developing their research belong to the Federal University of Sao Carlos (UFSCar - Brazil). The experiences to be reported provided the team with practical, as well as theoretical gains. In terms of practice we can cite: a more enthusiastic lesson planning and delivery, more consistent and balanced student evaluation system, motivating work atmosphere, and learning from each other teaching strategies. Regarding theoretical and professional development, there was the opportunity to study and discuss questions deriving from classroom observations, reflect about them and think of some possible, theoretically-based, routes to follow towards improving their practice. Concerning the co- 
taught students, they have become more actively involved in classes and revealed improvements in both, language skills and student responsibility profile.

Key-words: Teacher continued education; Collaborative teaching, Theoretical-practical analysis.

\section{Introduction}

In most graduate programs in Brazilian universities, Master Degree and PhD. students' goal is to follow a career that involves teaching (initially) at undergraduate programs in the major national universities. Considering that even having expertise in their research areas most of these professionals do not have formal education about classroom practice, $\mathrm{CAPES}^{1}$, the national agency that supervises and financially supports graduate programs nationwide, has passed a norm ${ }^{2}$ determining that all graduate students should be given the opportunity to have the experience to teach in cooperation with their research supervisors or other professors indicated by him/her. For those receiving a research grant this practice is obligatory.

Directly connected to this context, the aim of this paper is to report and discuss the experience that the authors had by collaboratively teaching undergraduate students (following CAPES norm) in two different classes, from diverse programs (one being a student-teacher education context and the other EAP), the first author (addressed as advisor, hereafter) supervises the $\mathrm{PhD}$. studies of the co-authors (graduate students, henceforth), the three of them involving Teaching English as a Foreign Language (TEFL).

Our co-teaching took place in two different moments, the first and second semesters of 2010, in two distinct settings. The first one being undergraduate classes for pre-service English teachers (PSETs) in their third year of education in a five-year-long Language and Literature Program at UFSCar and the second one in undergraduate

${ }^{1}$ CAPES - stands for Coordenação de Aperfeiçoamento de Pessoal de Nivel Superior (Coordination for the Improvement of Higher Education Professionals)

${ }^{2}$ Information about this norm can be found at: <http://ppgcc.dc.ufscar.br/ informacoes-sobre-o-pescd/normaspescd.pdf $>$. 
EAP (English for Academic Purposes) classes for first year students (FYSs) in a four-year-long Statistics Program at the same institution.

In our first experience, the collaboration consisted of classroom management help, when the advisor planned and taught most classes, discussing reasons for her choices with her graduate students, who collaborated with her by monitoring PSETs in the development of group work, besides taking notes about the reactions of the undergraduate students in different phases of the class. In the second co-teaching experience, the advisor set the challenges and suggested a plan to overcome challenges in the discipline, and the graduate students designed teaching activities and delivered most lessons, always observed by the advisor. In both occasions, there were online and on-site team meetings and discussions so that the four teachers could reflect about the development of the classes and the involvement/performance of the students.

Both opportunities have provided us with practical and theoretical gains, as well as, offered better learning opportunities to our undergraduate students. In this article, we present and discuss the impact of these co-teaching experiences in our professional lives, trying to reveal what a fruitful work can be done by the aggregation of the knowledge of experienced educators (researchers) and the skills and energy of young teachers (researchers).

\section{First co-teaching experience}

The goal of the class was developing PSET's writing skills based on the concept of genre analysis (especially Swales, 1990), and it aimed at developing students' autonomy in both, text production and editing. Taking into consideration that the group consisted of pre-service teachers, our main purpose was preparing them to select, write and edit texts and lesson plans based on fables, fairy tales, movie reviews, and advertisements, as genres that they are likely to deal with in future teaching practice.

In our first experience, most lessons were delivered by the advisor, and the graduate students observed classes, helped to review some teaching activities and assisted undergraduate students in activity development in small groups. We would say that in terms of categorizing 
this practice in the teaching models proposed by Dove and Honigsfeld (2010) it was similar, in some occasions, to the "multiple students groups", where two teachers (three, in our case) monitor and teach.

Due to the presence of more than one teacher in the classroom, once team-teaching had been established, group work during PSETs classes was facilitated, students had more opportunities of being assisted and supported, as reported by Carless (2006, p. 350) as one of the positive outcomes of team-teaching:

the presence of two teachers in the classroom can allow coteachers to provide more support for students and thereby group work becomes more practical. This can be particularly useful when classes are large or when there is a wide variety of abilities within a class.

Corroborating this idea, Stewart (2005, p. 10) points that in an effective partnership both students and teachers have gains, which are: 1) providing more attention and multiple perspectives for students and, 2) the opportunity for teacher growth and creativity.

As for pedagogical planning, the advisor proposed teaching activities that were presented for the graduate students before classes, so that they would help by giving suggestions, which were discussed by the team and finally, almost always, incorporated. Some of these discussions were carried in meetings, especially in the first and last months of the term, while most planning arrangements were conducted via e-mails. The meetings were necessary in the beginning of the term, because there were many decisions to be made and towards the end to establish feedback rubrics, as we wanted PSET's to understand which aspects of their writing were appropriate, the ones they needed to improve and how they could reach desirable skills. This procedure is in accordance with Stewart's words (2005, p. 8), who affirms that

"team teaching" involves much more than what happens in the classroom. Planning before courses and lessons is a vital aspect of the process when goals will need to be verbalized, negotiated and explained. This, in effect, is the essence of the dynamic and it carries on into the lesson and afterwards. 
Dove and Honigsfeld (2010) emphasize the importance of scheduled time for lesson planning in collaborative teaching, as managing regularly scheduled collaboration might be one of the challenges. In our experience, e-mail communication proved efficient most of the time.

Our main concern in this discipline was guiding PSETs (studentteachers) in developing autonomy in their writing, because of that many of the teaching activities aimed at collaborative work among them. After discussing and negotiating rubrics, it was PSETs' responsibility to review their colleagues' texts and offer them feedback. It was done in groups and assisted by the graduate students and the advisor. In the beginning, PSETs did not feel comfortable with this practice, because they thought it was the teacher's responsibility to offer students feedback. However, as time went by, they understood the purpose of that practice and even commented their gains, as can be seen in the following excerpts ${ }^{3}$ from questionnaires they have answered:

Because I can learn a little bit more and I can colaborate with my colleagues learning showing feedbacks. (PSET 3)

Because I can learn from my colleague's mistakes and rights. (PSET 1)

Because you can learn more with a colleague speach than with just the teacher's. (PSET 5)

Because I'm learning with their, I learn with right and mistakes them too. (PSET 6)

Because I like to see how people express theyselves: it can turn easy my way to express myself. (PSET 7)

In the implementation of this proposal, we have tried to build knowledge by integrating two teacher education levels, the PSETs and the graduate students. The former had a chance to experience a teacher's position when they had to review their colleagues' work, think of rubrics

\footnotetext{
${ }^{3}$ PSETs' observations are reproduced exactly the way they were presented in the questionnaires.
} 
and feedback. The latter were supposed to perform teacher educators' role, considering characteristics of teaching activities that would make the group more active and find ways to support PSETs' practice.

Considering DelliCarpini's (2009, p. 47) observation that: moving from transmitting knowledge to the construction of knowledge can have profound effects on the practice of teachers, it seems that our cooperation has created the possibility of contributing to the growth of both groups of professionals, student-teachers and research teachers.

\section{Second co-teaching experience}

The second time that the authors co-taught, graduate students planned and taught most (undergraduate) classes, observed by colleagues and the advisor. The teaching setting consisted of undergraduate EAP classes for first year students in a four-year-long Statistics Program at a federal university in Brazil.

We consider this experience what Stewart (2005, p. 3) calls the highest level of collaboration regarding the fact that the course was co-planned, co-taught and evaluated by a pair or a group of teachers.

This class aimed at preparing students to read academic statistics texts. It was offered in the first year of the program due to time allotment restriction in the course syllabus, but most students were still not aware of their explicit needs regarding English for academic purposes, as their contact with the statistics science was still limited. Based on this assumption (derived from previous practical experience), the class under analysis was planned to raise students' awareness of the number of studies and information in their area that is published in English. We expected to engage them in the development of the lessons, so we tried to have the group more active, aiming at enhancing/generating motivation.

As postulated by authors as Brown (1994), Pintrich and Schunk (1996), Guimarães (2001) and Stipek (2002), when students have the opportunity to be active, to participate, make choices, and give opinion, they get more engaged and intrinsically motivated to learn and, presenting this type of motivation, students increase the probability to succeed, because they create and explore the opportunities to learn and challenge themselves. 
Bearing the characteristics of this discipline in mind and expecting to overcome some of the challenges of that context, we spent about twenty hours (five meetings) together, planning how to design a class that might enhance students' participation and interest. Magalhães (2008, p. 110) points out that establishing collaborative contexts can be seen as a complex task. It is not only about organizing ways of people sitting together and taking parts in discussions. The context must be organized so that

it allows participants to engage in a course of action in which co-building is likely to take place; and in which everyone feels comfortable to show their different understandings, their different points of view - thus making this a meaningful dialogue for all involved.

We came to the conclusion that it would be proper to include some activities in which students would need to bring and evaluate information about statistics. They should choose a theme of their interest, such as environment, health, sports, religion (and so on) and then select a text where statistics had been used to report and support ideas. Later, they were asked to post their texts in a blog and the whole class had to post comments based on $\operatorname{six}^{4}$ (to select 2) guiding questions proposed by the team of teachers. Taking into consideration that there were 22 students enrolled and that they were performing this activity

${ }^{4}$ Guiding questions:

1. Which were the methods of data collection and analysis? Which are the elements in the text that support your answer? In case they are not explicit in the text, please conduct a research, infer and justify your answer (conclusions).

2. What is the importance of statistics to: A. the science that the text refers to? B. the society as a whole?

3. What is the statistician's role in the accomplishment of the study reported in the text?

4. What new information have you learned from the text as: A. a citizen? B. a professional (statistician)?

5. Based on your background knowledge, what information could you add to the text? Why?

6. What is your opinion about the information presented in the text? Give reasons to support your idea. 
in pairs, there was enough work for them to be engaged with throughout the term.

As pointed by Raby (2007, p. 187), The relationship between technology and L2 motivation in language learning somehow appears to be taken for granted: Information and Communication Technologies (ICT) favour motivation, so, considering that improving motivation was one of our main concerns, the blog seemed to be a good choice to enhance the students engagement, consequently the learning process.

The undergraduate students answered three questionnaires during the term, and based on their answers, as well as on their class behavior, we noticed that our goals had been reached. Many of them mentioned that the blog activities, besides providing them with the possibility of choosing relevant themes to read/write about, had contributed to enhance their knowledge not only of the English language and text comprehension, but also of statistics itself, making them more aware of future job possibilities and offering the group general culture.

Furthermore, FYSs commented on the gains concerning collaborative teaching while answering the questionnaires applied. Even thought it was not the main focus of the questionnaire, there was a specific question to investigate their opinion about the co-teaching practice. Some of the comments were translated (they were originally answered in Portuguese) as follows to illustrate this point.

I think it's interesting, because in spite of the fact that they (teachers) are teaching the same subject, each one has a different way to explain and that makes the class more dynamic and interesting. (FYS 15)

Great! Because each teacher has her own way to teach and think, this way we can learn the same thing, but in different manners. (FYS 2)

I think it's great, because some times more than one person is needed to help with the work in class. (FYS 8)

I think it's interesting having a team of teachers in the classroom, because the class became more dynamic, and we (students) received more attention from you (teachers). (FYS 19) 
In terms of the collaborative experience, the team work was essential in providing us with the necessary encouragement and motivation to implement the design of innovative learning activities as well as to put them into operation. The graduate students' skills in technology were vital in this case, as they had not only created, but also fed the blog.

Working together in monitoring and assisting students was also crucial in meeting the goals we had set. As FYSs were supposed to answer questions in the blog, write short compositions, and send exercises answers by e-mail, an amount of work was created. Had not been for the possibility of sharing the responsibility of providing students with feedback, the same practice would have been hardly done. Dove and Honigsfeld (2010) emphasize, among other benefits of cooperative teaching, the decrease of teacher isolation and the sharing of responsibility. As a consequence, according to the authors, what once might have been "my students" and "your students" turn into "our students". We can attest that the outcomes of counting on colleagues that embrace a group as "our students" makes a huge difference in one's everyday enthusiasm to conduct classes.

\section{Practical and theoretical gains for the team}

Considering that it is not usual for graduate students to have the formal opportunity of teaching at undergraduate programs, especially with the possibility of group reflection about this practice, we contend this co-teaching practice is a fertile environment to provide graduate students not only with their first experience, but also with valuable insights for their future professional practice.

According to Dove and Honigsfeld (2010, p. 14), mainstream teachers may initiate co-teaching with novice teachers who may not have experience with grade-level-appropriate content, scope and sequence of curriculum, local and state testing requirements, and so on. Although the graduate students involved in this team had previous teaching and curriculum development experience, they could be considered novice teachers in undergraduate disciplines.

Taking that into consideration, graduate students were more confident, because of being theoretically and practically assisted by the advisor, to implement their ideas and evaluate, in practice, strategies 
and techniques that had studied during their formal teacher education. Moreover, they were able to constantly reflect on their practice, which could be considered one of the positive results of co-teaching, as mentioned by DelliCarpini (2008):

Collaboration among teachers, teachers formulating their own questions about practice and student learning, and identifying challenges that are found in their own practice, guides teachers in becoming leaders and reflective practioners. In addition, it empowers teachers to take reflective action in their own classrooms.

Darling-Hammond and Richardson (2009 apud Dove and Honigsfeld, 2010, p. 12) by conducting a review research about the characteristics on effective teacher learning and professional development propose a list of eight main factors influencing effective teacher learning, among these, based on our experience, we would highlight the one asserting that teachers learn more effectively when (...) they are empowered to acquire new knowledge, apply it to their own practice, and reflect on the results.

It was also found how involving and motivating team work can be, once it was possible to share suggestions, plan lessons, discuss about teaching and learning aspects, as well as insecurities and concerns. In addition, graduate students were given the chance of peer observing during classes, what provided rich opportunities to exchange professional ideas and varied teaching strategies. Similar gains were reported in the study of Vo and Nguyen (2010) that considered the need of young teachers to be observed and receive feedback.

Another positive finding about this kind of teacher development that could be mentioned was that the skills acquired can be used in other contexts by graduate students in their professional career.

As for the advisor, without the motivation of collaborative work, she would hardly have implemented all the innovations that took place in the classes. Graduate students had a lot to contribute in terms of new technology domain, what improved lesson planning and delivery. Besides that, for being closer to the undergraduates' generation, the $\mathrm{PhD}$. students could bridge the gap between what might be seen as motivating lessons by the advisor (officially in charge of the 
group) and the FYSs. Our cooperative experience revealed then consistent with Stewart and Perry's (2005, p. 14) observation that the effectiveness of team teaching partnerships ultimately depends on what each team member brings to the endeavor.

It would also be improbable that alone the advisor would have applied questionnaires, and taken notes on the development and outcomes of classes aiming at reflecting about them in the light of theory. Besides all the practical gains, such theoretical supported reflection gave us the opportunity of writing ${ }^{5}$ and presenting $^{6}$ the results of our cooperative teaching.

It seems coherent, then, to say that cooperative teaching is also productive in fomenting a significant teacher contemporary role, that is, generating theory. As pointed out by Cray and Currie (1996), teachers have an important position in theorizing about their practice. In similar basis, Vo and Nguyen (2010: 205) assert that generally speaking, teachers play a key role in changes to teaching methodology and contribute to improvements in the quality of education.

\section{A word about collaborative teaching and reflection process}

As we have seen, there are different ways of co-teaching or

${ }^{5}$ Published article: AUTORES (Informação retirada pois continha o nome dos autores deste artigo). Relato de uma experiência com autonomia na formação de professores de LI: caminhos, obstáculos e reflexões (Reflections about an experience with autonomy in EFL teacher education). In: A educação de professores línguas na contemporaneidade: Novos Olhares. Kleber Silva, organizador. Editora Pontes, 2011.

Manuscript under development: "Innovative practices in EAP for undergraduate students".

${ }^{6}$ XXVI JELI - Jornada de Ensino de Língua Inglesa (EFL Conference) Jaú - SP, Brazil, June 25 - 26, 2010.

Paper session: "Autonomia na formação de professores de LI". (Autonomy in EFL teacher education)

"Inglês para propósitos específicos (leitura): relação entre necessidades e motivação de alunos em formação acadêmica inicial" Presentation to be delivered at XVIII InPLA (Intercâmbio de Pesquisas em Linguística Aplicada), São Paulo - SP, Brazil, June23-25, 2011. 
teaching collaboratively: ranging from simply discussing reasons for choices in lesson planning and course design to lesson observations and note-taking for future discussion, and more participant practices, such as co-planning or even co-planning and co-teaching (lesson delivery). In our understanding, the decision on how much collaboration there should be and how it should be planned will depend on the team experience and purposes.

In the case reported here, the advisor was more in control in the first co-teaching experience, as we started with discussions about the reasons behind the planned program and activities of the discipline we would teach together. The group performed some reading and discussion about theory that supported the practice and there was notetaking (about class development) and some undergraduate monitoring in classes, both by the graduate students. Then, there were meetings for team reflection about a rationale between theory, pedagogical plan and practice.

The second time the group (of teachers) worked together, the lessons were co-planned and co-taught, because although the advisor still outlined the challenge that should be overcome and indicated a plan about how it might be reached, the graduate students designed most activities, delivered most classes and offered most of the feedback that the undergraduate students received. There was a lot of e-mail communication by the group, with the advisor revising activities and participating in every class.

Summing up, we would say that in teacher education the degree of involvement of the members with less experience should gradually increase, theoretical support is highly desirable, analysis of "present situation" (determining challenges, setting a plan) and previewing reflection tools, such as lesson development note taking and instruments to hear students' voice (such as interviews and questionnaires) are essential. It is also important to establish confidence by negotiating rubrics and being open minded that the whole group is likely to have something to teach and a lot to learn.

Aiming at presenting a clearer picture of how the process was established in the reported experiences, we present a summary of the main aspects in each of them (in Table 1), so that they can be visualized at a glance. 
Table 1 - Main aspects of the co-teaching experiences

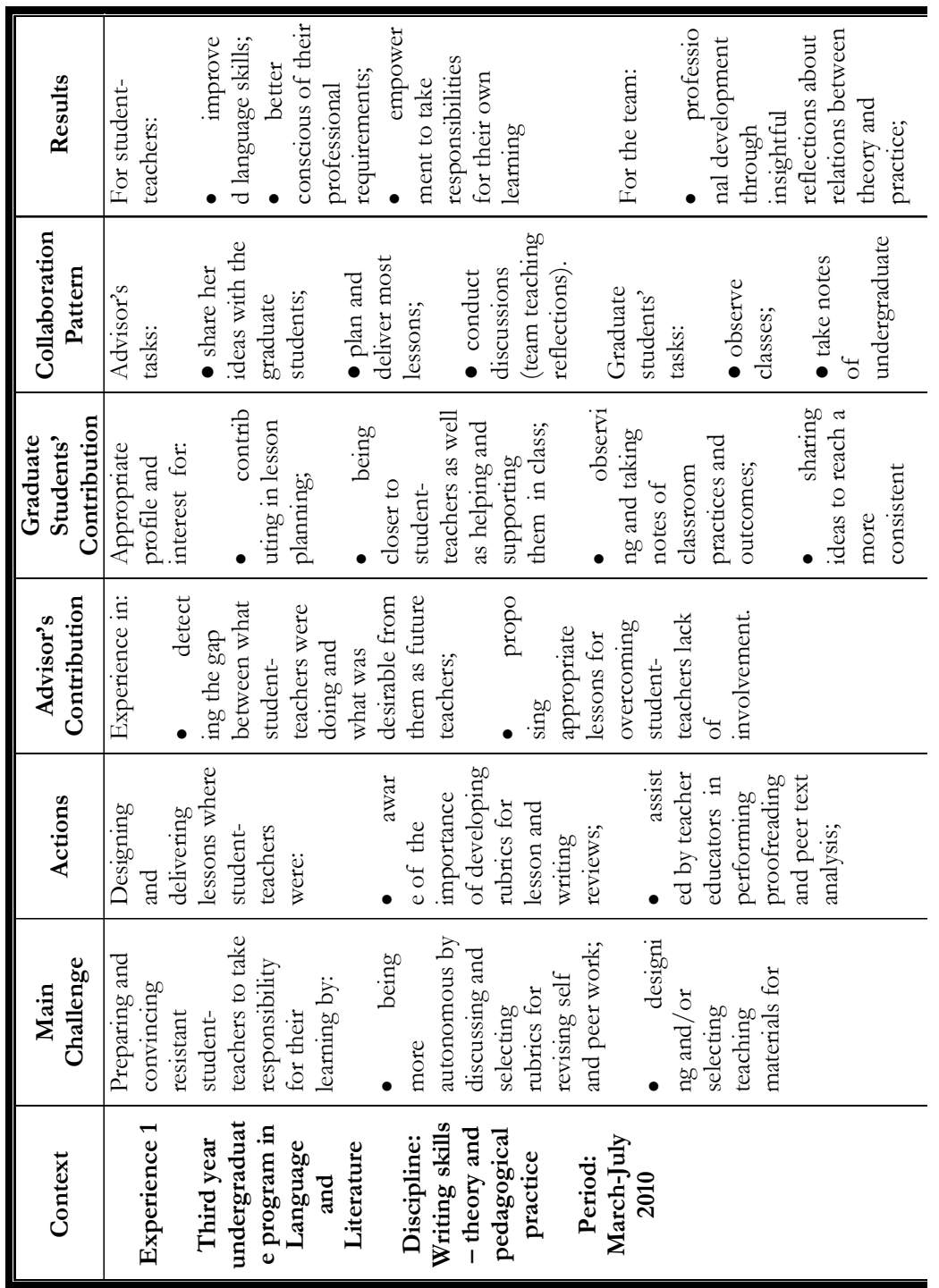




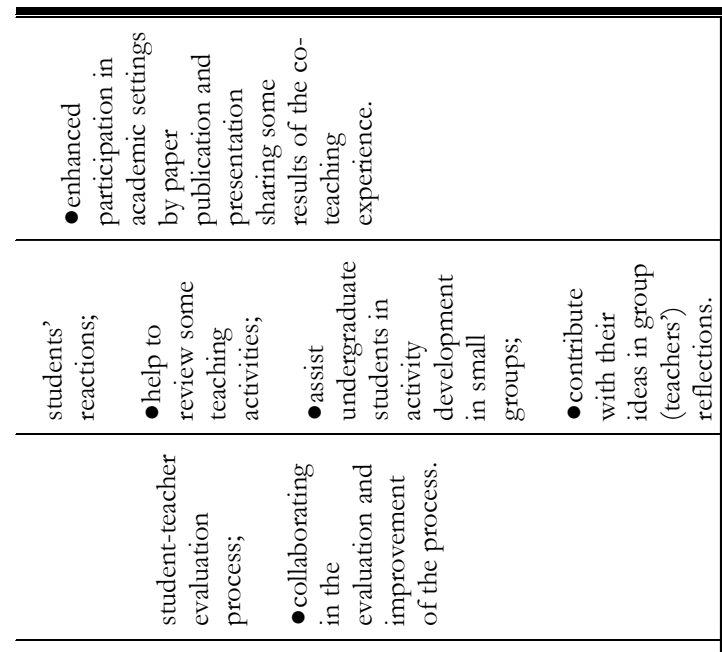

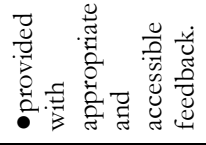

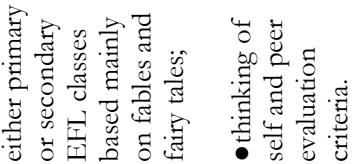




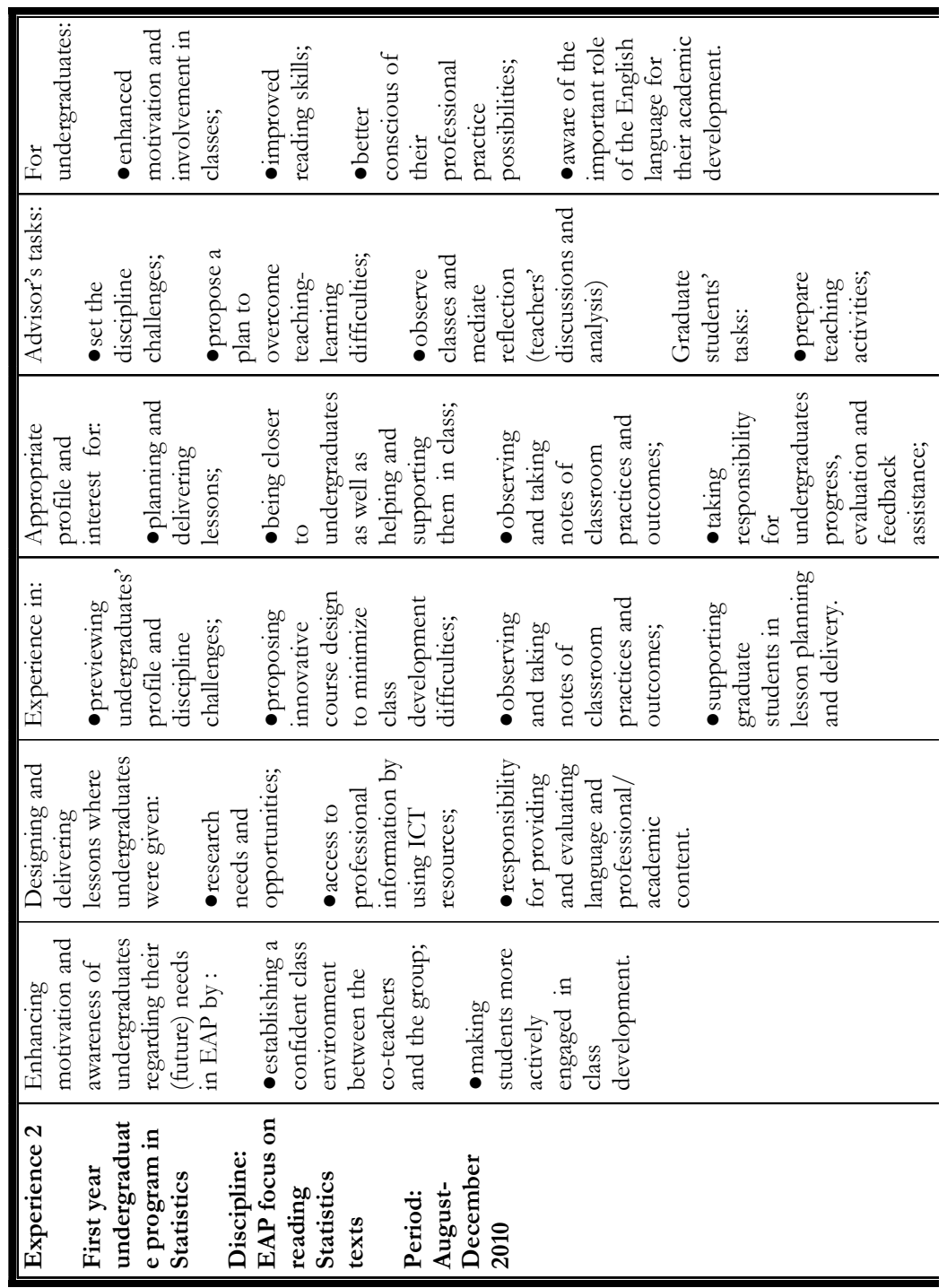




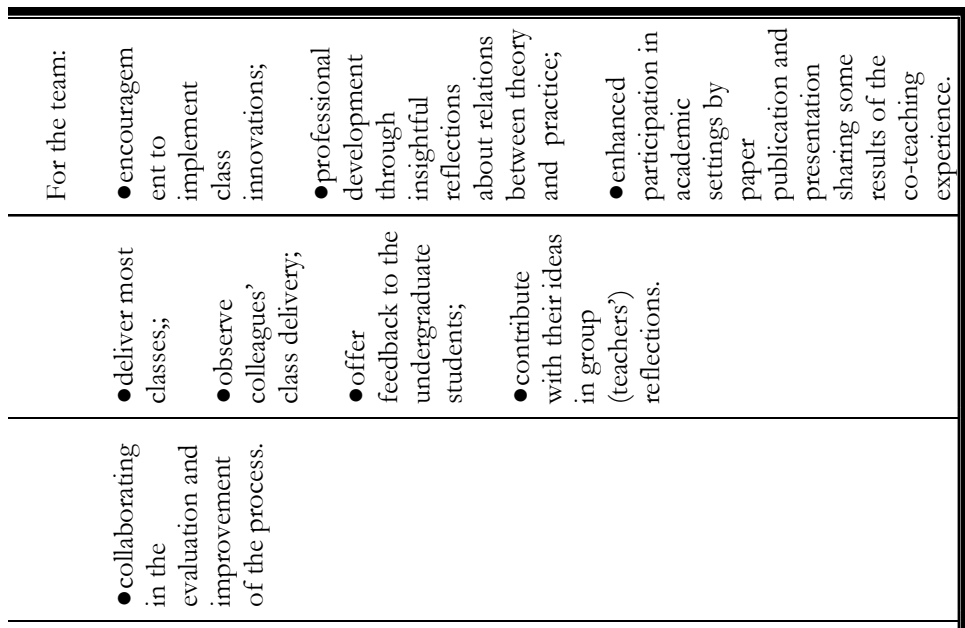




\section{Conclusion}

The two co-teaching experiences reported in this work have brought insightful professional gains for all the participants involved in the endeavors. The advisor had the opportunity to implement and reflect on the results of classroom practice ideas that she had in mind for quite some time. The graduate students could enrich their professional and academic skills, and the undergraduate students, by being given greater attention, had a chance to become more actively involved and responsible in their learning process.

All these benefits were reached because of the contribution that each member brought to the collaborative practices. Associating the advisor's experience with the graduate students skills and vitality was paramount in surpassing class challenges and making it possible to achieve the aims that had been established in the beginning of each term.

Although the experience is not probable to be repeated exactly the same way, the insights gained in the revitalization of the lessons, the curriculum innovations and the benefits for all the participants are likely to remain and, consequently, this experience points to the relevance that the practicum disciplines, traditionally offered at undergraduate programs, should be further proposed and investigated also in graduate programs, as at this level students seem to be better prepared to reflect on relations between theory and practice, and are likely to have and provide gains to the area of Applied Linguistics.

Furthermore, it would probably be possible and profitable to adopt collaboration patterns similar to those we have adopted even in pre-service teacher education, the amount of student-teacher (or teacher under continued education) responsibility, the appropriate theoretical readings, the forms of organizing group discussions and collecting data for subsequent reflection should be negotiated anew by each team and or occasion, depending on each one's working context. Nevertheless, setting goals (at times challenges), planning strategic actions, being theoretical founded and establishing an appropriate way to collect and analyze (reflect upon) class results is paramount in making collaborative teaching fruitful. 


\section{References}

BROWN, D. Teaching by principles. New Jersey: Prentice Hall, 1994.

CARLESS, D.R. Good practices in team teaching in Japan, South Korea and Hong Kong. System 34, p. 341-351, 2006. Retrieved from: $<$ www.sciencedirect.com>.

CRAY, E. and Currie, P. Linking adult learners with the education of L2 teachers. TESOL Quarterly, v. 30, n. 1, Spring 1996.

DELLICARPINI, M. Teacher collaboration for ESL/EFL academic success. Internet TESL Journal, v. 14, n. 8, 2008. Retrieved from < http:/ /iteslj.org >.

. Enhancing cooperative learning in TESOL teacher education. ELT Journal, v. 63, n. 1, Jan. 2009.

DOVE, M; HONIGSFELD, A. ESL Coteaching and Collaboration: Opportunities to Develop Teacher Leadership and Enhance Student Learning. TESOL Journal, v. 1, n. 1, Mar. 2010.

GUIMARÃES, S.E.R. A organização da escola e da sala de aula como determinante da motivação intrínseca e da meta aprender. In: BORUCHOVITCH, E.; BZUNECK, J.A. (Orgs). A motivação do aluno: contribuições da psicologia contemporânea. Petrópolis: Vozes, 2001. p.78-95.

MAGALHÃES, M.C.C. Teacher education language in collaborative and critical reflective contexts. In: GIL, G.; VIEIRA-ABRAHÃO, M.H. Educação de Professores de Linguas: os desafios do formador. Campinas: Pontes, 2008. p. 105-124.

PINTRICH, P. R.; SCHUNK, D.H. Motivation in education: theory, research, and applications. New Jersey: Prentice Hall, 1996.

RABY, F. A triangular approach to motivation in Computer Assisted Autonomous Language Learning (CAALL). ReCALL, v. 19, n. 2, p. 181-201, 2007. 
STEWART , T.; PERRY B. Interdisciplinary team teaching as a model for teacher development. TESL-EJ, v. 9, n. 2, Sep. 2005.

STIPEK, D. Motivation to learn: integrating theory to practice. Boston: Pearson Education, 2002.

SWALES, J.M. Genre analysis: English in academic and research settings. Cambrigde: Cambridge University Press, 1990.

VO, L.T.; NGUYEN, H.T.M. Critical Friends Group for EFL teacher professional development. ELT Journal, v. 64, n. 2, Apr. 2010. 